\title{
Squamous metaplasia of the rete ovarii do not suppress ovarian cyclicity and pregnancy in cattle: case report
}

[Metaplasia escamosa da rete ovarii não interrompe a ciclicidade ovariana e a gestação em bovinos: relato de caso]

\author{
Á.M. Borges ${ }^{1}$, C.H. Santana ${ }^{2}$, R.L. Santos ${ }^{l}$
}

Escola de Veterinária - Universidade Federal de Minas Gerais - Belo Horizonte, MG

${ }^{2}$ Aluna de pós-graduação - Escola de Veterinária - Universidade Federal de Minas Gerais - Belo Horizonte, MG

\begin{abstract}
Squamous metaplasia of the rete ovarii is an ovarian pathologic change characterized by replacement of the normal single layered cuboidal epithelium of the rete ovarii by a stratified squamous keratinized epithelium. Uterus and ovaries from a local slaughterhouse pregnant crossbreed cow were evaluated through ultrasound, macroscopically and histologically. Grossly, there were multiple cysts in both ovaries, which were histologically characterized as rete ovarii cysts with squamous metaplasia and intraluminal accumulation of keratinized material. Squamous metaplasia of the rete ovarii has been previously reported in cows, however this is the first report of this condition in a pregnant animal, demonstrating that this ovarian change is compatible with pregnancy.
\end{abstract}

Keywords: bovine, epidermoid cyst, ovary, rete ovarii, teratoma

\section{RESUMO}

A metaplasia escamosa da rete ovarii é uma patologia ovariana caracterizada pela substituição do epitélio simples cuboidal normal da rete ovarii por um epitélio estratificado escamoso queratinizado. Útero e ovários de uma vaca mestiça gestante, proveniente de abatedouro, foram avaliados por ultrassonografia, macroscopia e histologia. Verificaram-se vários cistos em ambos os ovários, histologicamente caracterizados como cistos de rete ovarii com metaplasia escamosa, com acúmulo intraluminal de material queratinizado. Metaplasia escamosa da rete ovarii foi relatada anteriormente em vacas, porém este é o primeiro relato em que essa alteração ovariana é compatível com manutenção da ciclicidde ovariana e gestação na vaca.

Palavras-chave: bovino, cisto epidermoide, ovários, rete ovarii, teratoma

\section{INTRODUCTION}

Squamous metaplasia of the rete ovarii is a recently recognized pathologic change of the ovary (Santos et al., 2012), which may have been misinterpreted as teratoma or epidermoid cysts (Santos et al., 2012). This ovarian change is characterized by replacement of the normal single layered cuboidal epithelium of rete ovarii by a keratinized stratified squamous epithelium, which results in accumulation of keratinized material within the lumen of the rete ovarii and consequently cystic dilatation.
A previous report described clinical, surgical, ultrasonographic, and histopathological findings, as well as the hormonal profile of a Zebu cow diagnosed with squamous metaplasia of the rete ovarii, which clearly demonstrated that this change did not compromise normal luteal ovarian activity (Borges et al., 2016). The goal of this study was to report a case of squamous metaplasia of rete ovarii in a pregnant Holstein $\mathrm{x}$ Zebu crossbreed cow demonstrating for the first time that this ovarian pathologic condition is compatible with pregnancy.

Recebido em 3 de novembro de 2020

Aceito em 9 de fevereiro de 2021

E-mail: alanmborges@ufmg.br 


\section{CASE REPORT}

Genital organs removed from one crossbreed Holstein x Zebu cow were submitted by a local slaughterhouse for pathological evaluation. No clinical or reproductive history was available. Postmortem ultrasound evaluation of uterine horns confirmed the pregnancy, and the size of embryonic vesicle and embryo were $30.6 \mathrm{~mm}$ and $21.0 \mathrm{~mm}$ (Figure 1), respectively. The ovaries were asymmetric and spherical. The left ovary was enlarged, measuring approximately $6.0 \times 4.5$ $x 3.5 \mathrm{~cm}$ (length, width and height, respectively), with an irregular surface with more than 10 cysts. Most of these cysts had a thin translucent wall, whereas a few of them had a white thick wall (Figure 1A).

These cysts ranged from 0.5 to $4.0 \mathrm{~cm}$ in diameter, and most of them were filled with a transparent liquid content, while a few of them had a whitish or yellowish mucous or dense inspissated material. The right ovary had approximately $4.0 \times 2.5 \times 2.0 \mathrm{~cm}$ (length, width and height, respectively), and contained developing follicles, a prominent dark brown mature corpus luteum, and two cystic structures with white thick wall measuring $2.2 \times 2.0 \mathrm{~cm}$ and $0.5 \times 0.4 \mathrm{~cm}$ (Figure 1B). In both ovaries there were dark brown older corpora albicantia indicating previous ovulations (Figure 1C).

The uterus and uterine tubes had no gross lesions, and the left uterine horn was asymmetric, and contained fluid, fetal membranes, and an embryonic vesicle measuring approximately $3 \times 2.5 \mathrm{~cm}$, compatible with 40 days of pregnancy (Figure 1D and E). Samples from both ovaries were fixed by immersion in $10 \%$ buffered formalin and processed for histopathology. Tissue sections were stained with hematoxylin and eosin. Histopathological analysis demonstrated multiple cystic structures with diameter ranging from 0.6 to $4.0 \mathrm{~cm}$, lined by single layered cuboidal epithelium normally found in the epithelium of the rete ovarii, with areas of multilayered epithelium. Cysts were filled with keratinized lamellar material. In some areas, there was abrupt transition from a single or multi-layered cuboidal epithelium to keratinized stratified squamous epithelium, and some cysts were filled with an acidophilic amorphous and acellular material (Figure 2).

\section{DISCUSSION}

Pathologic changes have been reported in the rete ovarii of a variety of mammalian species, including hyperplasia, adenomatous changes, cyst formation, and metaplasia in the rete ovarii in woman (Sauramo, 1954; Sharma et al., 2012). In veterinary medicine, enlarged rete ovarii is often due to accumulation of secretory material, characterizing cysts structures formation, which is named cystic rete ovarii, and it has been reported in different animal species (Nascimento and Santos, 2011), including cattle (Archbald et al., 1971), cats (Gelberg et al., 1984), and dogs, probably due to endocrine influence of phase of estrous cycle (O'Shea, 1966).

The normal rete ovarii is characterized by a network of anastomosed tubules lined by a single layered cuboidal or columnar epithelium (Gelberg et al., 1984; Wenzel and Odend'hal, 1985). Ovarian changes characterized by the development of cystic structures lined by stratified keratinizing squamous epithelium were earlier classified as benign teratomas (McEntee, 1990; Nascimento and Santos, 2011). However, the histopathological hallmark of teratomas is its tissue components derived from at least two of the three embryonic layers (ectoderm, mesoderm, and endoderm). More recently, bovine ovarian lesions containing stratified keratinizing squamous epithelium in the absence of skin adnexal structures or tissues from other embryonic tissue layers had been diagnosed as epidermoid cysts (Edwards, 2002), a terminology often found in the medical literature (Young $e t$ al., 1980; Sharma et al., 2012).

Santos et al. (2012) demonstrated that these cystic structures are unequivocally derived from the rete ovarii as a consequence of a metaplastic lesion. The simple cuboidal epithelium becomes a stratified epithelium, differentiates into squamous epithelium, producing keratinized material, and forming a cyst-like structure due to intraluminal accumulation of keratinized material. These authors first detailed a histopathological and immunohistochemistry description of squamous metaplasia of rete ovarii and suggested that the pathology does not prevent ovarian cyclicity. In spite of cystic changes occupying extensive areas in both ovaries, Santos et al. (2012) confirmed that the cow maintained ovarian cyclic activity, as 
evidenced by a mature and apparently functional corpus luteum and ovarian follicles in the ovary affected by the lesion. More recently, a second report by Borges et al. (2016) confirmed ovarian luteal activity with clinical, gynecological and endocrinological assessment in a Zebu cow, which confirmed that the cow was able to maintain ovarian follicular growth and ovulation followed by the development of a functional corpus luteum, as confirmed by normal blood levels of progesterone assessed by chemiluminescent enzyme immunoassay.
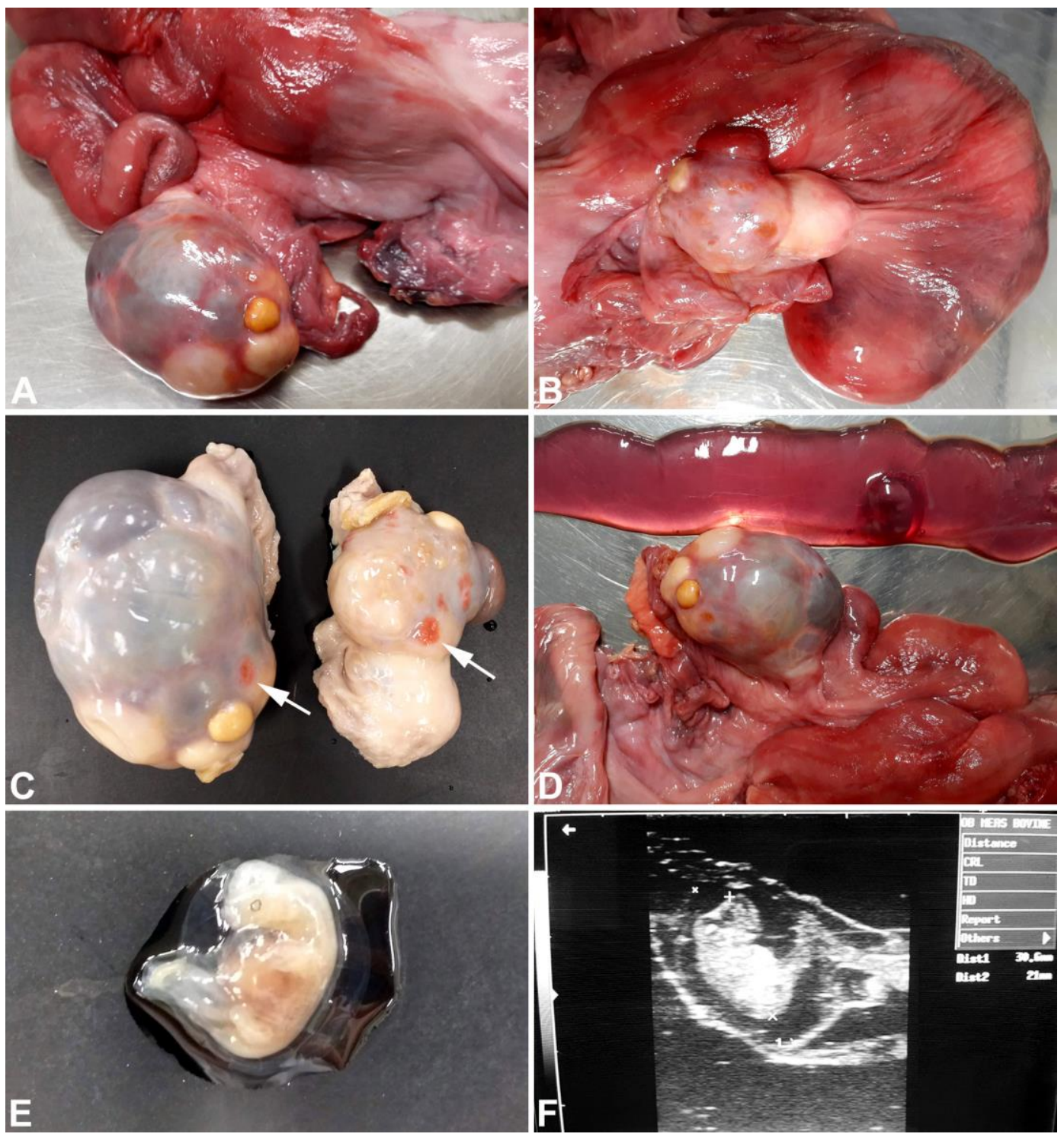

Figure 1. Gross appearance of bovine ovaries with squamous metaplasia of the rete ovarii. (A) Enlarged left ovary with an irregular surface containing multiple cysts. Most of the cysts are filled with a translucent fluid, while other cysts are filled with whitish mucous material or a dense keratinized material. (B) Right ovary with a corpus luteum and two cysts filled with whitish mucous material or a dense keratinized material. (C) Presence of dark brown older corpora albicantia in both ovaries (arrows) indicating previous ovulations. (D) Fetal membranes and a vesicle containing the embryo. (E) Bovine embryo surrounded by amniotic vesicle. (F) Ultrasound feature of the embryonic vesicle and embryo, precisely measuring 30.6 and $21.0 \mathrm{~mm}$, respectively. 


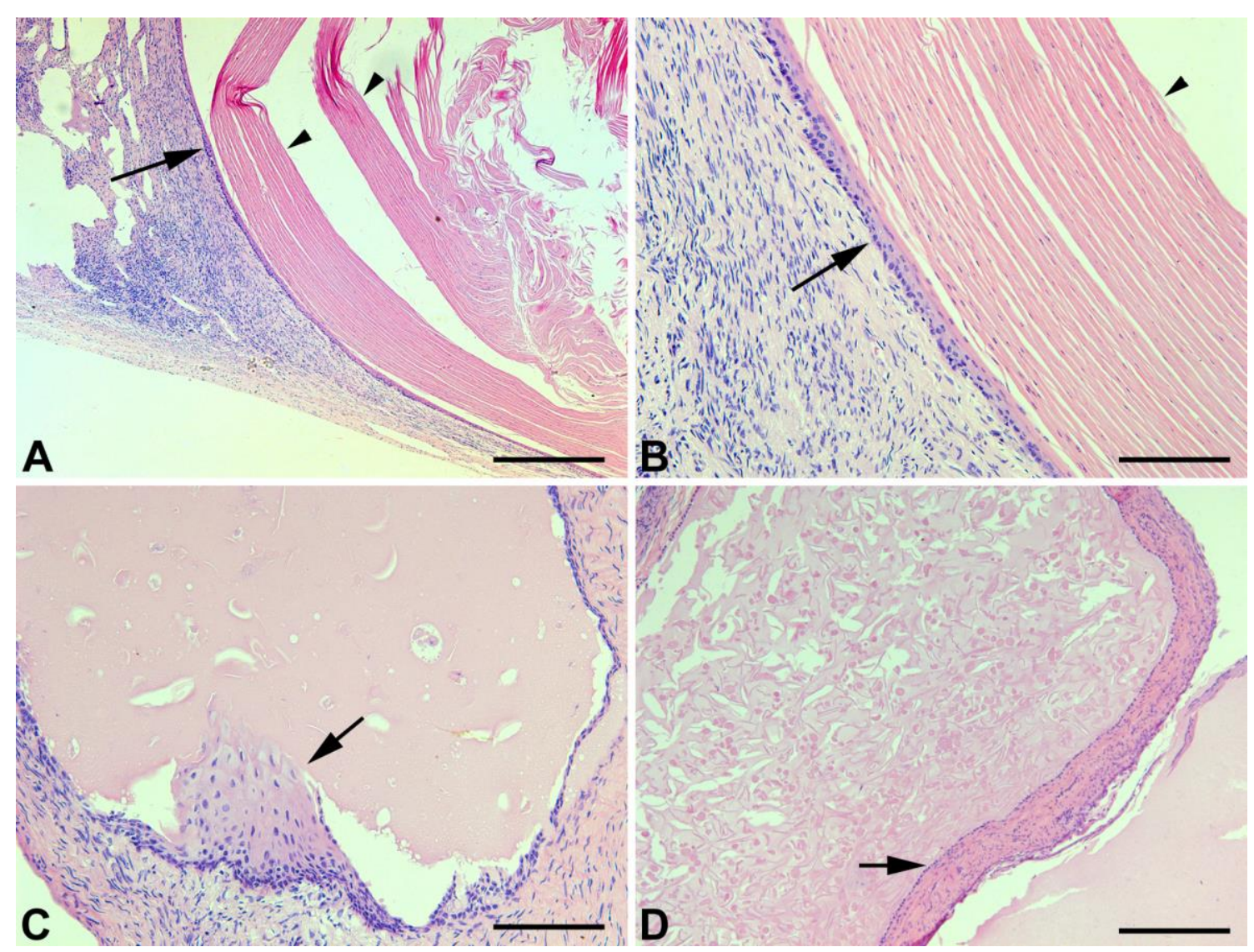

Figure 2. Squamous metaplasia of the rete ovarii in a crossbreed Holstein x Zebu cow. (A) Cystic cavity lined by keratinizing stratified squamous epithelium (arrow) and filled with lamellar keratinized material (arrowheads). Hematoxylin and eosin; bar $=500 \mu \mathrm{m}$. (B) Higher magnification of well differentiated keratinizing stratified squamous epithelium (arrow) and lamellar keratinized material (arrowhead). Hematoxylin and eosin; bar $=200 \mu \mathrm{m}$. (C) Cystic wall layered by an epithelium abruptly transitioning from a single or double layered epithelium to a keratinized stratified squamous epithelium (arrow). Hematoxylin and eosin; bar $=200 \mu \mathrm{m}$. (D) Cystic dilation of the rete ovarii, which is lined by its normal single layered cuboidal epithelium (arrow) and filled with a homogeneous eosinophilic material with large amount of keratinized material. Hematoxylin and eosin; bar $=500 \mu \mathrm{m}$.

In this case report we diagnosed ovarian cystic changes, secondary to squamous metaplasia of the rete ovarii, associated with follicles, dark brown older corpora albicantia indicating previous ovulations, a mature corpus luteum, associated with early pregnancy. Therefore, in spite of the size and location of the cystic structures, they did not interfere with capability of ovulation, corpus luteum formation, and pregnancy, indicating that this ovarian change is compatible with ovarian function and pregnancy. The crossbred Holstein x Zebu cow in this case was confirmed to be at approximately the fortieth day of gestation, with amniotic vesicle and embryo sized 30.6 and $21.0 \mathrm{~mm}$, respectively, as assessed by ultrasound. Therefore, this report demonstrated for the first time that the recently recognized ovarian pathologic change characterized by squamous metaplasia of the rete ovarii is compatible with pregnancy.

Histopathological findings in this case were quite similar to previously reported cases of squamous metaplasia of the rete ovarii (Santos et al., 2012; Borges et al., 2016). Epidemiologic data on prevalence and predisposing factors for metaplasia of the rete ovarii is missing, but this case along with the previously reported cases all affecting Zebu cows (Santos et al., 2012; Borges et al., 2016), support the notion that Zebu or crossbreed Zebu cows may be predisposed to the development of this lesion. 


\section{CONCLUSION}

In conclusion, here we described a case of squamous metaplasia of the rete ovarii in a pregnant crossbred Holstein $x$ Zebu cow. This report further expands our knowledge on this particular condition by demonstrating that squamous metaplasia of the rete ovarii is compatible with pregnancy in cattle.

\section{REFERENCES}

ARCHBALD, L.F.; SCHULTZ, R.H.; FAHNING, M.L. et al. Rete ovarii in heifers: a preliminar study. J. Reprod. Fertil., v.26, p.413414, 1971.

BORGES, A.M.; PEIXOTO, D.G.M.; PAIXÃO, T.A. et al. Clinical and pathological presentation of squamous metaplasia of the rete ovarii in a Zebu cow. Arq. Bras. Med. Vet. Zootec., v.68, p.17-21, 2016.

EDWARDS, J.F. Three cases of ovarian epidermoid cysts in cattle. Vet. Pathol., v.3, p.744-746, 2002.

GELBERG, H.B.; MCENTEE, K.; HEATH, E.H. Feline cystic rete ovarii. Vet. Pathol., v.21, p.304-307, 1984.

MCENTEE, K. Reproductive pathology of domestic mammals. San Diego: Academic Press, 1990. 491p.
NASCIMENTO, E.F.; SANTOS, R.L. Patologia da reprodução dos animais domésticos. 3.ed. Rio de Janeiro: Guanabara Koogan, 2011. 153p.

O'SHEA, J.D. Histochemical observations on mucin secretion by the subsurface epithelial structures in the canine ovary. J. Morphol., v.5, p.347-358, 1966.

SANTOS, R.L.; PEIXOTO, D.G.M.; TURCHETTI, A.P. et al. Squamous metaplasia of the rete ovarii in a Zebu cow. BMC Vet. Res., v.8, p.235-238, 2012.

SAURAMO, H. Development, occurrence, function and pathology of the rete ovarii. Acta Obstet. Gynecol. Scand., v.33, p.29-46, 1954.

SHARMA, N.; MANIMEKALAI; SONTI, S.; MEENAKSHISUNDARUM. A rare case of a giant epidermoid cyst of the ovary. J. Clin. Diag. Res., v.6, p.1584-1586, 2012.

WENZEL, J.G.W.; ODEND'HAL, S. The mammalian rete ovarii: a literature review. Cornell Vet., v.75, p.411-425, 1985.

YOUNG, R.H.; PRAT, J.; SCULLY, R.E. Epidermoid cyst of ovary: a report of three cases with comments on histogenesis. Am. J. Clin. Pathol., v.73, p.273-276, 1980. 